\title{
Prolixibacter bellariivorans gen. nov., sp. nov., a sugar-fermenting, psychrotolerant anaerobe of the phylum Bacteroidetes, isolated from a marine-sediment fuel cell
}

\author{
Dawn E. Holmes, ${ }^{1} \dagger$ Kelly P. Nevin, ${ }^{1} \dagger$ Trevor L. Woodard, ${ }^{1}$ \\ Aaron D. Peacock ${ }^{2}$ and Derek R. Lovley ${ }^{1}$ \\ 1Department of Microbiology, University of Massachusetts, Amherst, MA 01003, USA \\ ${ }^{2}$ The University of Tennessee Center for Biomarker Analysis, 10515 Research Drive, Suite \\ 300, Knoxville, TN 37932-2575, USA
}

Correspondence

Dawn E. Holmes

dholmes@microbio.umass.edu

\begin{abstract}
A Gram-negative, non-motile, filamentous, rod-shaped, non-spore-forming bacterium (strain $\mathrm{F}^{\top}{ }^{\top}$ ) was isolated from the surface of an electricity-harvesting electrode incubated in marine sediments. Strain $\mathrm{F} 2^{\top}$ does not contain c-type cytochromes, flexirubin or carotenoids. It is a facultative anaerobe that can ferment sugars by using a mixed acid fermentation pathway and it can grow over a wide range of temperatures $\left(4-42^{\circ} \mathrm{C}\right)$. The DNA G $+\mathrm{C}(44.9 \mathrm{~mol} \%)$ content and chemotaxonomic characteristics (major fatty acids, a-15:0 and 15:0) were consistent with those of species within the phylum Bacteroidetes. Phylogenetic analysis of the $16 \mathrm{~S}$ rRNA nucleotide and elongation factor $\mathrm{G}$ amino acid sequences indicated that strain $F 2^{\top}$ represents a unique phylogenetic cluster within the phylum Bacteroidetes. On the basis of 16S rRNA gene sequence phylogeny, the closest relative available in pure culture, Alkaliflexus imshenetskii, is only $87.5 \%$ similar to strain $\mathrm{F} 2{ }^{\top}$. Results from physiological, biochemical and phylogenetic analyses showed that strain $\mathrm{F} 2^{\top}$ should be classified as a novel genus and species within the phylum Bacteroidetes, for which the name Prolixibacter bellariivorans gen. nov., sp. nov. is proposed. The type strain is $\mathrm{F}^{\top}{ }^{\top}(=\mathrm{ATCC}$ BAA $-1284^{\top}=$ JCM $13498^{\top}$ ).
\end{abstract}

Electricity can be produced by sediment fuel cells placed in anoxic sediments: these cells contain natural populations of micro-organisms that transfer electrons to current-harvesting electrodes (Bond et al., 2002; Holmes et al., 2004b; Reimers et al., 2001; Tender et al., 2002). These electrons then flow to the cathode in the overlying aerobic water, where they react with oxygen. Several organisms that are able to oxidize organic acids, such as acetate, to $\mathrm{CO}_{2}$ and utilize an electrode as the sole electron acceptor have already been isolated (Bond et al., 2002; Bond \& Lovley, 2003, 2005; Chaudhuri \& Lovley, 2003; Holmes et al., 2004d). However, there has been very little emphasis on the role that fermentative organisms might play within the microbial community of the sediment fuel cell.

tThese authors contributed equally to this work.

Abbreviation: PFLA, phospholipid fatty acid.

The GenBank/EMBL/DDBJ accession numbers for the 16S rRNA and fusA gene sequences of strain $F 2^{\top}$ are AY918928 and AY918929, respectively.

The phospholipid fatty acid content (\%) of strain $\mathrm{F}^{\top}$ and a $16 \mathrm{~S}$ rRNA gene sequence similarity matrix for strain $\mathrm{F}^{\top}$ and other Bacteroidetes species are available in supplementary tables in IJSEM Online.
Molecular analyses of marine-sediment fuel cells have led to the suggestion that fermentative organisms account for approximately $10 \%$ of the microbial community present on the surfaces of current-harvesting anodes (Bond et al., 2002; Holmes et al., 2004b; Tender et al., 2002). In addition, micro-organisms with $16 \mathrm{~S}$ rRNA gene sequences most similar to those of fermentative micro-organisms have been detected on anodes from microbial fuel cells powered by other fuel sources, such as organic wastewater (Kim et al., 2004), activated sludge (Lee et al., 2003) and oligotrophic river water (Phung et al., 2004). In fact, when wastewater from a corn-processing plant was provided as the electron donor in a microbial fuel cell powered by activated sludge, up to $19 \%$ of the $16 \mathrm{~S}$ rRNA gene sequences detected were most similar to known fermentative micro-organisms from the phylum Bacteroidetes (Kim et al., 2004).

Although fermentative micro-organisms are important members of the electrode community, they are unlikely to be directly involved in current production by the microbial fuel cell. Several micro-organisms with fermentative types of metabolism have been able to grow and produce current in microbial fuel cells; however, electron transfer to the electrode performed by these organisms was very inefficient 
(Park et al., 2001; Pham et al., 2003). For example, when Clostridium butyricum was grown in an anodic chamber with glucose as the electron donor, only $0.04 \%$ of the electrons available in glucose were transferred to the electrode surface (Park et al., 2001) and less than $0.02 \%$ of the electrons available from yeast extract (calculated from the chemical oxygen demand, $250 \mathrm{mg} \mathrm{l}^{-1}$ ) were transferred to an electrode by Aeromonas hydrophila (Pham et al., 2003). In addition, only $\sim 25 \%$ of the electrons available from the incomplete oxidation of pyruvate, lactate and propionate were transferred to the electrode surface by Desulfobulbus propionicus, via a mixed fermentative metabolism (Holmes et al., 2004a).

Dissimilatory metal-reducing micro-organisms, on the other hand, are able to transfer $80-95 \%$ of the electrons available from the complete oxidation of an electron donor to a current-harvesting electrode (Bond \& Lovley, 2003; Chaudhuri \& Lovley, 2003; Holmes et al., 2004d). On the basis of these findings, it is likely that fermentative microorganisms that can convert complex organic matter in anaerobic sediments to fermentation products such as acetate are involved in the initial steps of power production by the microbial fuel cell. These side-products are then completely oxidized by dissimilatory metal-reducing microorganisms that are able to transfer electrons directly to the current-harvesting anode and produce a current.

Information concerning the role of fermentative microorganisms on electrodes will help in the optimization of microbial fuel cells capable of harvesting electricity from waste biomass produced by agricultural, municipal and industrial sources in which energy is primarily stored in the form of carbohydrates. Here we report the characterization of a novel strain of bacteria, strain $\mathrm{F}^{\mathrm{T}}$, isolated from the surface of an electricity-harvesting electrode incubated in marine sediments, that is likely to be a member of the fermentative niche within the microbial community on such electrodes.

Strain $\mathrm{F} 2^{\mathrm{T}}$ was isolated from a marine-sediment fuel cell that was constructed in the laboratory with sediments collected from Boston Harbour (MA, USA) near the World's End peninsula, at a water depth of $5 \mathrm{~m}$, as described previously (Bond et al., 2002; Holmes et al., 2004b). After incubation and energy harvesting at $15^{\circ} \mathrm{C}$ for 6 months, the anode was pulled from the sediment, washed with sterile anaerobic marine medium lacking electron donors or acceptors and containing $\mathrm{Na}_{2} \mathrm{~S}(1.0 \mathrm{mM})$ as a reducing agent. The anode surface was then scraped with a sterile razor blade into a slightly modified version of APW medium (Coates et al., 1995), referred to as A1 medium (Holmes et al., 2004d). Serial dilutions in $\mathrm{A} 1$ medium containing poorly crystalline $\mathrm{Fe}(\mathrm{III})$ oxide $(100 \mathrm{mM})$ provided as the electron acceptor and benzoate $(0.5 \mathrm{mM})$ as the electron donor yielded an enrichment culture comprising three organisms: a Geopsychrobacter species, a Fusibacter species and strain $\mathrm{F}^{\mathrm{T}}$. In order to separate this tri-culture and isolate strain $\mathrm{F}^{\mathrm{T}}{ }^{\mathrm{T}}$, eight 10 -fold serial dilutions, with glucose $(5 \mathrm{mM})$ provided as the fermentation substrate, were performed at $22{ }^{\circ} \mathrm{C}$. The highest dilutions that were able to grow were diluted to extinction three more times and were then transferred to solidified medium ( $2 \%$ agar) with glucose $(5 \mathrm{mM})$. Isolated colonies were then selected and grown in A1 medium supplemented with glucose $(5 \mathrm{mM})$.

For morphological and phenotypic characterization, strain $\mathrm{F} 2^{\mathrm{T}}$ was cultivated under anoxic conditions $\left(\mathrm{N}_{2} / \mathrm{CO}_{2}\right.$; $80: 20, \mathrm{v} / \mathrm{v})$ in $\mathrm{A} 1$ medium with galactose $(6 \mathrm{mM})$ as the fermentation substrate. Growth on an electrode was tested as previously described (Bond et al., 2002; Bond \& Lovley, 2003) and utilization of the various electron donors and acceptors was only considered positive after four transfers ( $5 \%$ inoculum). The end-products of glucose fermentation were analysed with a high-pressure liquid chromatograph (series 1100; Hewlett Packard) on a Fast Acid Analysis column (Bio-Rad) with an eluant of $5 \mathrm{mM} \mathrm{H}_{2} \mathrm{SO}_{4}$ and absorbance detection at $210 \mathrm{~nm}$. Strain $\mathrm{F}^{\mathrm{T}}$ exhibited a mixed acid fermentative metabolism when grown on glucose; the end products included acetate, succinate and propionate.

Temperature, $\mathrm{pH}$ and salinity ranges were determined as described previously (Nevin et al., 2005). For salinity characterization tests, media contained $\mathrm{NaCl}$ without any divalent salts. There was no requirement for seawater. The API 20NE test (bioMérieux) was used according to the manufacturer's directions, with cells grown anaerobically with galactose $(5-6 \mathrm{mM})$ as the fermentation substrate. Strain $\mathrm{F} 2^{\mathrm{T}}$ was positive for hydrolysis of aesculin and gelatin, indole production, $\beta$-galactosidase activity and arabinose assimilation and was negative for reduction of nitrate and nitrite, glucose fermentation, arginine dihydrolase, urease and the assimilation of glucose, mannose, mannitol, $\mathrm{N}$ acetylglucosamine, maltose, potassium gluconate, capric acid, adipic acid, malic acid, trisodium citrate and phenylacetic acid. Growth on urease agar, MacConkey agar and DNase agar, acid production from sucrose and glucose, indole production, capnophilic metabolism and gliding motility were assessed using standard tests. Strain $\mathrm{F}^{\mathrm{T}}{ }^{\mathrm{T}}$ was found to be negative for growth on urease, DNase agar and MacConkey agar, and negative for acid production from sucrose and glucose, capnophilic metabolism and gliding motility. The strain was sensitive to penicillin. Pigment production was determined by using two methods: for flexirubin, the $\mathrm{KOH}$ method (Reichenbach et al., 1974) was used; for carotenoids, an acetone extraction method was used to produce an absorption spectrum (Denger et al., 2002). For cytochrome determinations, whole-cell suspensions were analysed using dithionite-reduced and airoxidized spectra (350-700 nm) by using a UV2401-PC dual-beam spectrophotometer (Shimadzu). No peaks were observed in the dithionite-reduced minus air-oxidized difference spectrum of strain $\mathrm{F}^{\mathrm{T}}{ }^{\mathrm{T}}$, a result that is consistent with the absence of $c$-type cytochromes. The results from these tests are shown, in comparison with those for genera within the phylum Bacteroidetes, in Table 1. The physiology 
Table 1. Phenotypic characteristics of strain $\mathrm{F}^{\top}$ and members of the phylum Bacteroidetes

Taxa: 1, Strain $\mathrm{F}^{\mathrm{T}}$; 2, Alkaliflexus imshenetskii DSM $15055^{\mathrm{T}} ; 3$, Anaerophaga thermohalophila DSM $12881^{\mathrm{T}} ; 4$, Marinilabilia salmonicolor DSM $6480^{\mathrm{T}}$; 5 , Cytophaga fermentans DSM $9555^{\mathrm{T}}$; 6, Pedobacter cryoconitis DSM $14825^{\mathrm{T}}$. All of the taxa shown utilized cellobiose $(2.5 \mathrm{mM})$, glucose $(5 \mathrm{mM})$, mannose $(2 \mathrm{mM})$, starch $\left(1 \mathrm{~g}^{-1}\right)$ and xylose $(2 \mathrm{mM})$. NT, Not tested.

\begin{tabular}{|c|c|c|c|c|c|c|}
\hline Characteristic & 1 & 2 & 3 & 4 & 5 & 6 \\
\hline Origin & $\begin{array}{l}\text { Marine-sediment } \\
\text { fuel cell }\end{array}$ & Soda lake & Oilfield & Marine & Marine & $\begin{array}{c}\text { Glacier } \\
\text { cryoconite }\end{array}$ \\
\hline Cell size $(\mu \mathrm{m})$ & $0.33 \times 10.5-12.5$ & $0.25-0.4 \times 4-10$ & $0.3 \times 4-8$ & $0.3-0.5 \times 2-6$ & $0.5-0.7 \times 2-10$ & $0.7-0.9 \times 1.5-3.0$ \\
\hline Motility & Not observed & Gliding & Not observed & Gliding & Gliding & Gliding \\
\hline Colour & White & Pink & Orange-red & $\begin{array}{l}\text { Yellow to } \\
\text { salmon pink }\end{array}$ & Bright yellow & Light yellow \\
\hline DNA G +C content (mol\%) & 44.9 & 44.3 & 41.8 & 37 & 39 & 43.4 \\
\hline Pigment & None detected & Carotenoid & $\begin{array}{c}\text { Carotenoid }+ \\
\text { flexirubin }\end{array}$ & NT & NT & NT \\
\hline $\mathrm{O}_{2}$ metabolism & $\begin{array}{l}\text { Facultatively } \\
\text { anaerobic }\end{array}$ & $\begin{array}{c}\text { Anaerobic; low } \\
\mathrm{O}_{2} \text { tolerance }\end{array}$ & Strictly anaerobic & $\begin{array}{l}\text { Facultatively } \\
\text { anaerobic }\end{array}$ & $\begin{array}{l}\text { Facultatively } \\
\text { anaerobic }\end{array}$ & Aerobic \\
\hline \multicolumn{7}{|l|}{$\mathrm{pH}$ for growth: } \\
\hline Optimum & 7.0 & 8.5 & 6.8 & $7.0-7.5$ & NT & $6-7$ \\
\hline Range & $5.0-9.0$ & $7.2-10.2$ & NT & NT & NT & $5-8$ \\
\hline \multicolumn{7}{|l|}{ Temperature for growth $\left({ }^{\circ} \mathrm{C}\right)$ : } \\
\hline Optimum & 22 & 35 & 55 & $28-37$ & 30 & 20 \\
\hline Range & $4-42$ & $10-45$ & $37-55$ & NT & NT & $1-25$ \\
\hline \multicolumn{7}{|l|}{$\mathrm{NaCl}$ for growth $\left(\mathrm{g} \mathrm{l}^{-1}\right)$ : } \\
\hline Optimum & 20 & 20 & $20-60$ & NT & NT & NT \\
\hline Range & $5-80$ & $0.8-53$ & $20-120$ & $10-30$ & $<30$ & NT \\
\hline Catalase & - & + & - & + & + & + \\
\hline \multicolumn{7}{|l|}{ Substrates: } \\
\hline Arabinose $(10 \mathrm{mM})$ & - & + & + & + & + & - \\
\hline Agar $\left(1 \mathrm{~g} \mathrm{l}^{-1}\right)$ & - & - & NT & - & + & + \\
\hline Cellulose $\left(1 \mathrm{~g} \mathrm{l}^{-1}\right)$ & - & - & - & NT & - & NT \\
\hline Fructose $(2 \mathrm{mM})$ & - & - & + & + & + & + \\
\hline Galactose $(2,6$ and $10 \mathrm{mM})$ & + & + & + & + & - & + \\
\hline Lactose $(10 \mathrm{mM})$ & + & - & + & + & + & + \\
\hline Maltose (5 mM) & + & + & NT & + & + & + \\
\hline Trehalose (2 mM) & + & + & + & + & - & + \\
\hline References & This study & $\begin{array}{l}\text { Zhilina et al. } \\
\quad(2004)\end{array}$ & $\begin{array}{c}\text { Denger \& Schink } \\
\text { (1995); Denger } \\
\text { et al. (2002) }\end{array}$ & $\begin{array}{l}\text { Reichenbach } \\
\text { (1992); Suzuki } \\
\text { et al. (1999) }\end{array}$ & $\begin{array}{l}\text { Reichenbach } \\
\text { (1992) }\end{array}$ & $\begin{array}{l}\text { Margesin } \\
\text { et al. (2003) }\end{array}$ \\
\hline
\end{tabular}




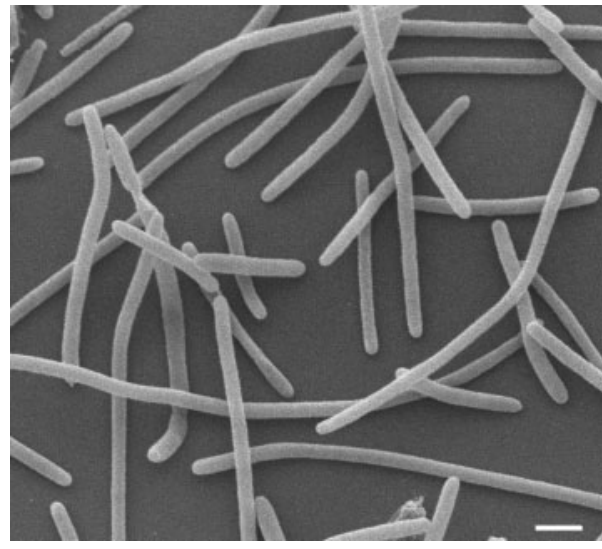

Fig. 1. Scanning electron micrograph of cells of strain $F 2^{\top}$ grown on medium with glucose $(5 \mathrm{mM})$ as the fermentative substrate. Bar, $1 \mu \mathrm{m}$.

of strain $\mathrm{F}^{\mathrm{T}}$ was most similar to that of Alkaliflexus imshenetskii.

Cell morphology was observed under a Nikon Eclipse E600 microscope. Electron microscopic observations were performed in the microscopy facility at the University of Massachusetts, Amherst (Fig. 1).

The phospholipid fatty acid (PLFA) composition (Pinkart et al., 2002), the double-bond geometry and the positions of monounsaturated PLFAs were determined by using previously described techniques (Dunkelblum et al., 1985). Seventeen major PLFAs and 15 trace PLFAs were observed in strain $\mathrm{F}^{\mathrm{T}}$ (see Supplementary Table S1 available in IJSEM Online). The major PLFAs were as follows: a-15:0 (23.29\%), $15: 0$ (20.73\%), i- $15: 0(13.65 \%), 17: 0(8.78 \%)$, $16: 0 \quad(5.63 \%)$, i- $16: 0 \quad(4.51 \%), 17: 1 \omega 8 \quad(3.40 \%)$, i$17: 1 \omega 8 \mathrm{a} \quad(3.16 \%)$, a- $17: 0 \quad(2.83 \%), \quad \mathrm{i}-14: 0 \quad(2.45 \%)$, i-16: $1 \omega 7$ (2.40\%), a-17: $1 \omega 8$ (1.80\%), i-17:0 (1.49\%), a- $15: 1 \omega 8(1.03 \%), 15: 1 \omega 6(0.78 \%), \mathrm{i}-17: 1 \omega 8 b(0.75 \%)$ and $16: 1 \omega 7 c(0.72 \%)$. PFLA analysis showed that $35.1 \%$ of the fatty acids in strain $\mathrm{F}^{\mathrm{T}}$ were normal saturated, $48.2 \%$ were terminally branched saturated, $9.14 \%$ were branched monounsaturated and $4.90 \%$ were monounsaturated. The fatty acid composition of strain $\mathrm{F}^{\mathrm{T}}$ was similar to those of other species within the phylum Bacteroidetes (Alkaliflexus imshenetskii, Marinilabilia salmonicolor and Anaerophaga thermohalophila) (Table 2).

Analysis of the DNA G + C content (Cashion et al., 1997) was performed by the Identification Service of the Deutsche Sammlung von Mikrooganismen and Zellkulturen (Braunschweig, Germany). Genomic DNA for the 16S rRNA gene and $f u s A$, the gene that encodes elongation factor G, sequence analysis was extracted using the FastDNA spin kit (BIO 101) according to the manufacturer's instructions. The $16 \mathrm{~S}$ rRNA gene sequence for strain $\mathrm{F}^{\mathrm{T}}$ was amplified with primers 8 forward (Lane et al., 1985; Lane, 1991) and 1492 reverse (Achenbach \& Woese, 1995; Amann et al., 1990) as
Table 2. Fatty acid contents (\%) of strain $F 2^{\top}$ and three related Bacteroidetes species

Taxa: 1, strain $\mathrm{F}^{\mathrm{T}} ; 2$, Alkaliflexus imshenetskii DSM $15055^{\mathrm{T}} ; 3, \mathrm{M}$. salmonicolor DSM $6480^{\mathrm{T}} ; 4$, Anaerophaga thermohalophila DSM $12881^{\mathrm{T}}$. Data for taxa 2-4 are from Zhilina et al., 2004.

\begin{tabular}{|c|c|c|c|c|}
\hline Fatty acid & 1 & 2 & 3 & 4 \\
\hline \multicolumn{5}{|l|}{ Straight chain } \\
\hline $13: 0$ & 0.09 & 1.1 & - & - \\
\hline $14: 0$ & 0.20 & - & - & 1.8 \\
\hline $15: 0$ & 20.73 & 39.0 & 19.5 & 4.7 \\
\hline $16: 0$ & 5.63 & 1.0 & 12.2 & 9.5 \\
\hline $17: 0$ & 8.78 & - & 3.4 & - \\
\hline $18: 0$ & 0.06 & - & 4.6 & 3.3 \\
\hline $15: 1$ & 0.78 & 4.1 & - & - \\
\hline $16: 1$ & 0.98 & - & - & - \\
\hline $17: 1$ & 3.40 & - & - & - \\
\hline $18: 1$ & - & - & 5.4 & 1.9 \\
\hline $18: 2$ & - & - & 4.6 & - \\
\hline \multicolumn{5}{|c|}{ Branched chain } \\
\hline$i-13: 0$ & 0.12 & 1.4 & - & - \\
\hline $\mathrm{i}-14: 0$ & 2.45 & 1.1 & - & 1.9 \\
\hline $\mathrm{i}-15: 0$ & 13.65 & 29.4 & 11.3 & 30.2 \\
\hline $\mathrm{i}-16: 0$ & 4.51 & 1.0 & 2.1 & 2.9 \\
\hline $\mathrm{i}-17: 0$ & 1.49 & - & - & - \\
\hline$i-15: 1$ & 0.41 & - & - & - \\
\hline i-16: 1 & 2.64 & - & - & - \\
\hline $\mathrm{i}-17: 1$ & 3.91 & - & - & - \\
\hline$a-13: 0$ & 0.03 & - & - & - \\
\hline a-15:0 & 23.29 & 11.6 & 31.7 & 21.2 \\
\hline$a-17: 0$ & 2.83 & - & 2.0 & - \\
\hline$a-15: 1$ & 1.03 & - & - & - \\
\hline$a-17: 1$ & 1.80 & 3.5 & - & - \\
\hline br-14: 1 & 0.02 & - & - & - \\
\hline br-18: 1 & 0.35 & - & - & - \\
\hline $17: 0 \mathrm{cy}$ & - & 4.0 & - & - \\
\hline \multicolumn{5}{|l|}{ 3-Hydroxyl } \\
\hline 3-OH-15:0 & 0.45 & 2.4 & - & 5.1 \\
\hline $3-\mathrm{OH}-16: 0$ & 0.32 & - & - & 3.4 \\
\hline $3-\mathrm{OH}-\mathrm{i}-16: 0$ & - & - & - & 2.3 \\
\hline 3-OH-i-17:0 & - & - & 3.3 & 7.8 \\
\hline
\end{tabular}

described previously (Holmes et al., 2004c). A gene fragment from the fus $A$ gene in strain $\mathrm{F}^{2}{ }^{\mathrm{T}}$ was amplified with primers fusAf and fusAr (Berchet et al., 2000) as described previously (Holmes et al., 2004c). The 16S rRNA and fusA gene fragments were compared with the GenBank nucleotide and protein databases using the BLASTN and BLASTX algorithms (Altschul et al., 1990). Nucleotide and amino acid sequences were manually aligned and hypervariable regions were masked in the Genetic Computer Group (GCG) sequence editor (Wisconsin Package, version 10). Aligned sequences were imported into PAUP 4.0b 4a (Swofford, 1998) in which the phylogenetic trees were inferred. The branching order was determined and compared with those obtained using 
maximum-parsimony, maximum-likelihood and distancebased algorithms. Similarity matrices were generated using ALIGN (Pearson, 1990).

Phylogenetic analysis of $16 \mathrm{~S}$ rRNA and fusA gene sequences indicated that strain $\mathrm{F}^{\mathrm{T}}$ clusters within the phylum Bacteroidetes in the Bacteria (Fig. 2). Strain $\mathrm{F}^{\mathrm{T}}{ }^{\mathrm{T}}$ is unique in that the most similar 16S rRNA gene sequence from an organism that is available in pure culture (Alkaliflexus imshenetskii) has a similarity of only $87.5 \%$ (see Supplementary Table S2 available in IJSEM Online). The amino acid sequence of elongation factor $\mathrm{G}$ from strain $\mathrm{F} 2^{\mathrm{T}}$ was also only $71 \%$ similar to that of another species within the Bacteroidetes, Porphyromonas gingivalis.

Although organisms phylogenetically related to strain $\mathrm{F} 2^{\mathrm{T}}$ are not available in pure culture, the $16 \mathrm{~S}$ rRNA gene sequence from an uncultured organism detected in 2bromophenol-dehalogenating and phenol-degrading consortia (Knight et al., 1999) was $97.2 \%$ similar to that of strain $\mathrm{F} 2^{\mathrm{T}}$. These results are interesting, as sediments previously collected from Boston Harbour were contaminated with polycyclic aromatic hydrocarbons (Hayes \& Lovley, 2002; Hayes et al., 1999; McGroddy \& Farrington, 1995; McGroddy et al., 1996; Rothermich et al., 2002; Rudnick \& Chen, 1998; Wang et al., 2001). Other uncultured $16 \mathrm{~S}$ rRNA gene sequences closely related to that of strain $\mathrm{F}^{\mathrm{T}}$ have been detected in permanently cold marine environments, such as sediments from the Arctic Ocean (Ravenschlag et al., 1999), the Japan Trench land slope (Li et al., 1999) and Antarctic sea ice (Brown \& Bowman, 2001). Again, this is not very surprising, as strain $\mathrm{F}^{\mathrm{T}}$ is capable of growth at temperatures as low as $4{ }^{\circ} \mathrm{C}$. On the basis of physiological, biochemical and phylogenetic data, strain $\mathrm{F}^{\mathrm{T}}$ represents a novel genus and species within the phylum Bacteroidetes, for which the name Prolixibacter bellariivorans gen. nov., sp. nov. is proposed.

\section{Description of Prolixibacter gen. nov.}

Prolixibacter [Pro.lix'i.bac.ter. L. adj. prolixus - a -um long, extended; N.L. masc. n. bacter (from Gr. n. bakterion) a rod; N.L. masc. n. Prolixibacter a long rod].

Comprises long, filamentous, curved rods that occur as single, non-motile cells. Cells do not have pili or flagella and do not form spores. Cell-wall structure is typical of a Gramnegative bacterium. Cells do not contain $c$-type cytochromes and are oxidase- and catalase-negative. Organisms in this genus can grow at temperatures as low as $4{ }^{\circ} \mathrm{C}$ and consist of facultative anaerobes that can ferment sugars by a mixed acid fermentation pathway. The genus Prolixibacter is in the phylum Bacteroidetes in the Bacteria. The type species is Prolixibacter bellariivorans.

\section{Description of Prolixibacter bellariivorans sp. nov.}

Prolixibacter bellariivorans [bell.ar.ii'vorans. L. pl. n. bellaria sweets, dessert; L. part. adj. vorans (from L. v. vorare) (a)

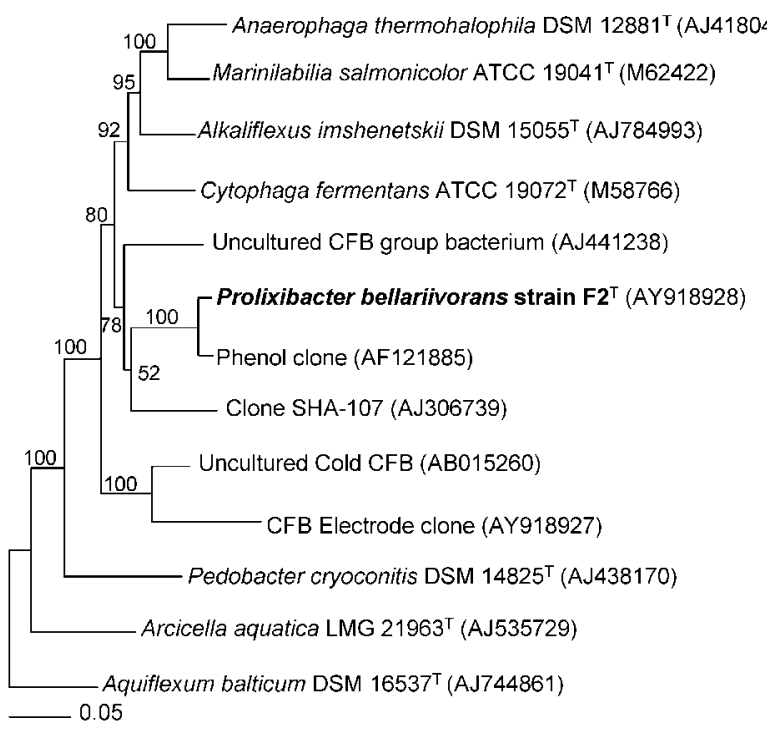

(b)

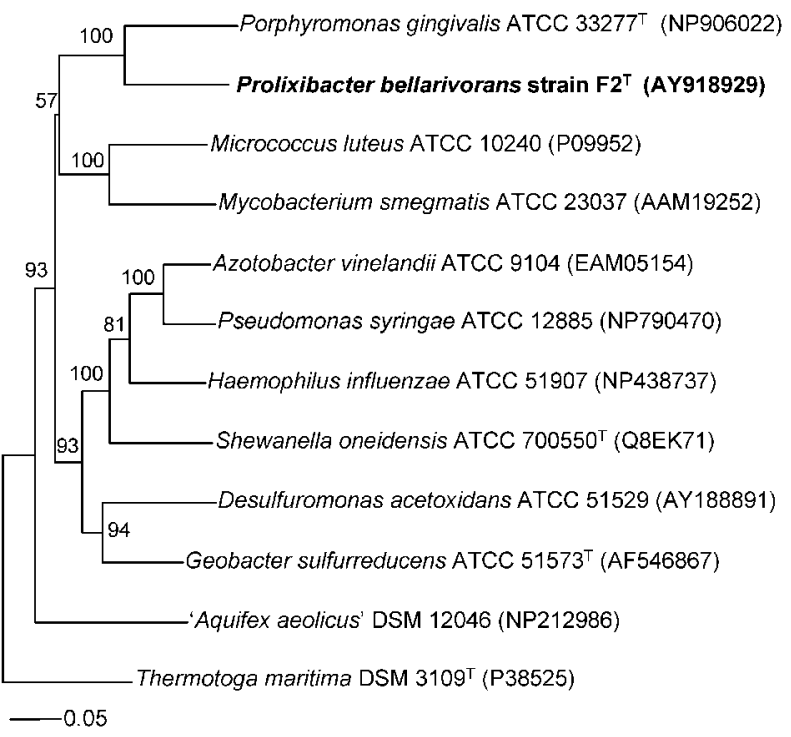

Fig. 2. Phylogenetic trees comparing (a) $16 \mathrm{~S}$ rRNA gene sequences and (b) elongation factor $\mathrm{G}$ amino acid sequences from various species. The phylogenetic tree comparing $16 \mathrm{~S}$ rRNA gene sequences was constructed by using Jukes-Cantor distance-based analysis with Pedobacter cryoconitis, Arcicella aquatica and Aquiflexum balticum as the outgroups. The phylogenetic tree comparing the elongation factor $\mathrm{G}$ amino acid sequences was constructed by using maximum-parsimony analysis with Thermotoga maritima as the outgroup. CFB, Cytophaga-Flavobacterium-Bacteroides. Bars, (a) 0.05 nucleotide substitutions per site, (b) 0.05 amino acid changes. 
devouring; N.L. part. adj. bellariivorans sweet-devouring, consuming sweet things].

Exhibits the following properties in addition to those given in the genus description. Cells are approximately 10.5$12.5 \mu \mathrm{m}$ in length and $0.33 \mu \mathrm{m}$ in diameter. Growth is observed when atmospheric oxygen is provided as the electron acceptor, with galactose as the electron donor. Cannot utilize nitrate, $\mathrm{Fe}$ (III)-pyrophosphate, Fe(III)citrate, $\mathrm{Fe}(\mathrm{III})$-oxide, $\mathrm{Fe}(\mathrm{III})$-nitrilotriacetic acid, sulfate, thiosulfate or a graphite electrode poised at $+200 \mathrm{mV}$ as an electron acceptor. Under anaerobic conditions, can ferment arbutin $(5 \mathrm{mM})$, cellobiose, aesculin $\left(1 \mathrm{~g} \mathrm{l}^{-1}\right)$, galactose $(6 \mathrm{mM})$, lactose, maltose, mannose, melezitose $(2.5 \mathrm{mM})$, melibiose $(2.5 \mathrm{mM})$, methyl D-glucoside $(5 \mathrm{mM})$, raffinose $(2 \mathrm{mM})$, salicin $(10 \mathrm{mM})$, starch $\left(1 \mathrm{~g} \mathrm{l}^{-1}\right)$, sucrose $(5 \mathrm{mM})$, trehalose $(2 \mathrm{mM})$, turanose $(2.5 \mathrm{mM})$, xylose and yeast extract $\left(0.5 \mathrm{~g} \mathrm{l}^{-1}\right)$. Substrates tested but not utilized include acetate $(10 \mathrm{mM})$, acetoin $\left(1 \mathrm{~g} \mathrm{l}^{-1}\right)$, adonitol $(5 \mathrm{mM})$, alginate $\left(1 \mathrm{~g} \mathrm{l}^{-1}\right)$, arginine $(5 \mathrm{mM})$, benzoate $(2 \mathrm{mM})$, 2,3-butanediol $\left(0.9 \mathrm{~g} \mathrm{l}^{-1}\right)$, butyrate $(10 \mathrm{mM})$, caproate $(10 \mathrm{mM})$, carrageenan $\left(1 \mathrm{~g} \mathrm{l}^{-1}\right)$, Casamino acids $\left(1 \mathrm{~g} \mathrm{l}^{-1}\right)$, casein $(10 \mathrm{mM})$, citrate $(10 \mathrm{mM})$, ethanol $(10 \mathrm{mM})$, ferulate $(10 \mathrm{mM})$, formate $(10 \mathrm{mM})$, fucose $(2.5 \mathrm{mM})$, fumarate $(10 \mathrm{mM})$, gallic acid $\left(0.5 \mathrm{~g} \mathrm{l}^{-1}\right)$, gelatin $\left(1 \mathrm{~g} \mathrm{l}^{-1}\right)$, glycerol $(6 \mathrm{mM}), \beta$-hydroxybutyrate $(1$ and $4 \mathrm{mM})$, hydrogen $(130 \mathrm{kPa})$ with $0.1 \mathrm{mM}$ acetate provided as a carbon source for growth, inulin $\left(1 \mathrm{~g} \mathrm{l}^{-1}\right)$, isobutyrate $(10 \mathrm{mM})$, lactate $(10 \mathrm{mM})$, malate $(10 \mathrm{mM})$, malonate $(10 \mathrm{mM})$, mannitol $(10 \mathrm{mM})$, methyl $\alpha$-D-mannoside $(5 \mathrm{mM})$, nicotinate $(10 \mathrm{mM})$, polyethylene glycol $\left(1 \mathrm{~g} \mathrm{l}^{-1}\right)$, proline $(10 \mathrm{mM})$, propionate $(10 \mathrm{mM})$, pyrogallol $\left(0.5 \mathrm{~g} \mathrm{l}^{-1}\right)$, pyruvate $(10 \mathrm{mM})$, rhamnose $(10 \mathrm{mM})$, ribose $(10 \mathrm{mM})$, serine $(10 \mathrm{mM})$, sorbitol $(5 \mathrm{mM})$, sorbose $(10 \mathrm{mM})$, succinate $(10 \mathrm{mM})$, syringate $(10 \mathrm{mM})$, tryptone $\left(1 \mathrm{~g} \mathrm{l}^{-1}\right)$, valerate $(10 \mathrm{mM})$, nitrate $(5 \mathrm{mM})$ plus $\mathrm{Fe}(\mathrm{III})$-pyrophosphate $(20 \mathrm{mM})$ [with acetate $(10 \mathrm{mM})$, citrate $(10 \mathrm{mM})$, galactose $(2.5 \mathrm{mM})$ or lactate $(10 \mathrm{mM})]$, atmospheric oxygen with [acetate $(10 \mathrm{mM})$, citrate $(10 \mathrm{mM})$ or lactate $(10 \mathrm{mM})]$, and a graphite electrode with [acetate $(10 \mathrm{mM})$ or galactose $(6 \mathrm{mM})]$. Growth occurs at temperatures between 4 and $42^{\circ} \mathrm{C}$, with an optimum at $22^{\circ} \mathrm{C}$. The optimal $\mathrm{pH}$ is 7.0 .

The type strain, $\mathrm{F}^{\mathrm{T}}\left(=\right.$ ATCC BAA- $1284^{\mathrm{T}}=\mathrm{JCM} 13498^{\mathrm{T}}$ ), was isolated from the surface of an electricity-harvesting electrode incubated in marine sediments.

\section{References}

Achenbach, L. \& Woese, C. (1995). $16 \mathrm{~S}$ and $23 \mathrm{~S}$ rRNA-like primers. In Archaea: a Laboratory Manual, pp. 201-203. Edited by F. T. Robb, A. R. Place, K. R. Sowers, H. J. Schreier, S. DasSarma \& E. M. Fleischmann. Cold Spring Harbor, NY: Cold Spring Harbor Laboratory.

Altschul, S. F., Gish, W., Miller, W., Myers, E. W. \& Lipman, D. J. (1990). Basic local alignment search tool. J Mol Biol 215, 403-410.
Amann, R. I., Binder, B. J., Olson, R. J., Chisholm, S. W., Devereux, R. \& Stahl, D. A. (1990). Combination of $16 \mathrm{~S}$ rRNA-targeted oligonucleotide probes with flow cytometry for analyzing mixed microbial populations. Appl Environ Microbiol 56, 1919-1925.

Berchet, V., Thomas, T., Cavicchioli, R., Russell, N. J. \& Gounot, A. M. (2000). Structural analysis of the elongation factor $G$ protein from the low-temperature-adapted bacterium Arthrobacter globiformis SI55. Extremophiles 4, 123-130.

Bond, D. R. \& Lovley, D. R. (2003). Electricity production by Geobacter sulfurreducens attached to electrodes. Appl Environ Microbiol 69, 1548-1555.

Bond, D. R. \& Lovley, D. R. (2005). Evidence for involvement of an electron shuttle in electricity generation by Geothrix fermentans. Appl Environ Microbiol 71, 2186-2189.

Bond, D. R., Holmes, D. E., Tender, L. M. \& Lovley, D. R. (2002). Electrode-reducing microorganisms that harvest energy from marine sediments. Science 295, 483-485.

Brown, M. V. \& Bowman, J. P. (2001). A molecular phylogenetic survey of sea-ice microbial communities (SIMCO). FEMS Microbiol Ecol 35, 267-275.

Cashion, P., Holder-Franklin, M., McCully, J. \& Franklin, M. (1997). A rapid method for the base determination of bacterial DNA. Anal Biochem 81, 461-466.

Chaudhuri, S. K. \& Lovley, D. R. (2003). Electricity generation by direct oxidation of glucose in mediatorless microbial fuel cells. Nat Biotechnol 21, 1229-1232.

Coates, J. D., Lonergan, D. J., Philips, E. J., Jenter, H. \& Lovley, D. R. (1995). Desulfuromonas palmitatis sp. nov., a marine dissimilatory $\mathrm{Fe}(\mathrm{III})$ reducer that can oxidize long-chain fatty acids. Arch Microbiol 164, 406-413.

Denger, K. \& Schink, B. (1995). New halo- and thermotolerant fermenting bacteria producing surface-active compounds. Appl Environ Microbiol 52, 173-178.

Denger, K., Warthmann, R., Ludwig, W. \& Schink, B. (2002). Anaerophaga thermohalophila gen. nov., sp. nov. a moderately thermophilic, strictly anaerobic fermentative bacterium. Int J Syst Evol Microbiol 52, 173-178.

Dunkelblum, E., Tan, S. H. \& Silk, P. J. (1985). Double-bond location in monounsaturated fatty acids by dimethyl disulfide derivatization and mass spectrometry: application to analysis of fatty acids in pheromone glands of four Lepidoptera. J Chem Ecol 11, 265-277.

Hayes, L. A. \& Lovley, D. R. (2002). Specific $16 \mathrm{~S}$ rDNA sequences associated with naphthalene degradation under sulfate-reducing conditions in harbor sediments. Microb Ecol 43, 134-145.

Hayes, L. M., Nevin, K. P. \& Lovley, D. R. (1999). Role of prior exposure on anaerobic degradation of naphthalene and phenanthrene in marine harbor sediments. Org Geochem 30, 937-945.

Holmes, D. E., Bond, D. R. \& Lovley, D. R. (2004a). Electron transfer by Desulfobulbus propionicus to Fe(III) and graphite electrodes. Appl Environ Microbiol 70, 1234-1237.

Holmes, D. E., Bond, D. R., O'Neil, R. A., Reimers, C. E., Tender, L. R. \& Lovley, D. R. (2004b). Microbial communities associated with electrodes harvesting electricity from a variety of aquatic sediments. Microb Ecol 48, 178-190.

Holmes, D. E., Nevin, K. P. \& Lovley, D. R. (2004c). Comparison of $16 \mathrm{~S}$ rRNA, nifD, recA, rpoB and fusA genes within the family Geobacteraceae fam. nov. Int J Syst Evol Microbiol 54, 1591-1599.

Holmes, D. E., Nicoll, J. S., Bond, D. R. \& Lovley, D. R. (2004d), Potential role of a novel psychrotolerant member of the family Geobacteraceae, Geopsychrobacter electrodiphilus gen. nov., sp. nov., in electricity production by a marine sediment fuel cell. Appl Environ Microbiol 70, 6023-6030 
Kim, B. H., Park, H. S., Kim, H. J., Kim, G. T., Chang, I. S., Lee, J. \& Phung, N. T. (2004). Enrichment of microbial community generating electricity using a fuel-cell-type electrochemical cell. Appl Microbiol Biotechnol 63, 672-681.

Knight, V. K., Kerkhof, L. J. \& Häggblom, M. M. (1999). Community analyses of sulfidogenic 2-bromophenol-dehalogenating and phenoldegrading microbial consortia. FEMS Microbiol Ecol 29, 137-147.

Lane, D. L. (1991). 16S/23S rRNA sequencing. In Nucleic Acid Techniques in Bacterial Systematics, pp. 115-175. Edited by E. Stackebrandt \& M. Goodfellow. Chichester: Wiley.

Lane, D. L., Pace, B., Olsen, G. J., Stahl, D., Sogin, M. L. \& Pace, N. R. (1985). Rapid determination of $16 \mathrm{~S}$ ribosomal RNA sequences for phylogenetic analysis. Proc Natl Acad Sci U S A 82, 6955-6959.

Lee, J. Y., Phung, N. T., Chang, I. S., Kim, B. H. \& Sung, H. C. (2003). Use of acetate for enrichment of electrochemically active microorganisms and their 16S rDNA analyses. FEMS Microbiol Lett 223, 185-191.

Li, L., Kato, C. \& Horikoshi, K. (1999). Microbial diversity in sediments collected from the deepest cold-seep area, the Japan Trench. Mar Biotechnol 1, 391-400.

Margesin, R., Sproer, C., Schumann, P. \& Schinner, F. (2003). Pedobacter cryoconitis sp. nov., a facultative psychrophile from alpine glacier cryoconite. Int J Syst Evol Microbiol 53, 1291-1296.

McGroddy, S. E. \& Farrington, J. W. (1995). Sediment porewater partitioning of polycyclic aromatic hydrocarbons in three cores from Boston Harbor, Massachusetts. Environ Sci Technol 29, 1542-1550.

McGroddy, S. E., Farrington, J. W. \& Gschwend, P. M. (1996). Comparison of the in situ and desorption sediment-water partitioning of polycyclic aromatic hydrocarbons and polychlorinated biphenyls. Environ Sci Technol 30, 172-177.

Nevin, K. P., Holmes, D. E., Woodard, T. L., Hinlein, E. S., Ostendorf, D. W. \& Lovley, D. R. (2005). Geobacter bemidjiensis sp. nov. and Geobacter psychrophilus sp. nov., two novel Fe(III)-reducing subsurface isolates. Int J Syst Evol Microbiol 55, 1667-1674.

Park, H. S., Kim, B. H., Kim, H. S., Kim, H. J., Kim, G. T., Kim, M., Chang, I. S., Park, Y. K. \& Chang, H. I. (2001). A novel electrochemically active and $\mathrm{Fe}$ (III)-reducing bacterium phylogenetically related to Clostridium butyricum isolated from a microbial fuel cell. Anaerobe 7, 297-306.

Pearson, W. R. (1990). Rapid and sensitive sequence comparisons with FASTP and FASTA. Methods Enzymol 183, 63-98.

Pham, C. A., Jung, S. J., Phung, N. T., Lee, J., Chang, I. S., Kim, B. H., Yi, H. \& Chun, J. (2003). A novel electrochemically active and Fe(III)reducing bacterium phylogenetically related to Aeromonas hydrophila, isolated from a microbial fuel cell. FEMS Microbiol Lett 223, 129-134.
Phung, N. J., Lee, J., Kang, K. H., Chang, I. S., Gadd, G. M. \& Kim, B. H. (2004). Analysis of microbial diversity in oligotrophic microbial fuel cells using $16 \mathrm{~S}$ rDNA sequences. FEMS Microbiol Lett 233, 77-82.

Pinkart, H. C., Ringelberg, D. B., Piceno, Y. M., Macnaughton, S. J. \& White, D. C. (2002). Manual of Environmental Microbiology, 2nd edn. Washington, DC: American Society for Microbiology.

Ravenschlag, K., Sahm, K., Pernthaler, J. \& Amann, R. (1999). High bacterial diversity in permanently cold marine sediments. Appl Environ Microbiol 65, 3982-3989.

Reichenbach, H. (1992). The Order Cytophagales. In The Prokaryotes, pp. 3631-3675. Edited by A. Balows, H. G. Truper, M. Dworkin, W. Harder \& K.-H. Schleifer. New York: Springer.

Reichenbach, H., Kleinig, H. \& Achenbach, H. (1974). The pigments of Flexibacter elegans. Novel and chemosystematically useful compounds. Arch Microbiol 101, 131-134.

Reimers, C. E., Tender, L. M., Fertig, S. \& Wang, W. (2001). Harvesting energy from the marine sediment-water interface. Environ Sci Technol 35, 192-195.

Rothermich, M. M., Hayes, L. A. \& Lovley, D. R. (2002). Anaerobic, sulfate-dependent degradation of polycyclic aromatic hydrocarbons in petroleum-contaminated harbor sediment. Environ Sci Technol 36, 4811-4817.

Rudnick, S. M. \& Chen, R. F. (1998). Laser-induced fluorescence of pyrene and other polycyclic aromatic hydrocarbons (PAH) in seawater. Talanta 47, 907-919.

Suzuki, M., Nakagawa, Y., Harayama, S. \& Yamamoto, S. (1999). Phylogenetic analysis of genus Marinilabilia and related bacteria based on the amino acid sequences of $g y r B$ and emended description of Marinilabilia salmonicolor with Marinilabilia agarovorans as its subjective synonym. Int J Syst Bacteriol 49, 1551-1557.

Swofford, D. L. (1998). PAUP*: Phylogenetic analysis using parsimony (* and other methods), version 4. Sunderland, MA: Sinauer Associates.

Tender, L. M., Reimers, C. E., Stecher, H. A., Holmes, D. E., Bond, D. R., Lowy, D. A., Pilobello, K., Fertig, S. J. \& Lovley, D. R. (2002). Harnessing microbially generated power on the seafloor. Nat Biotechnol 20, 821-825.

Wang, X. C., Zhang, Y. X. \& Chen, R. F. (2001). Distribution and partitioning of polycyclic aromatic hydrocarbons (PAHs) in different size fractions in sediments from Boston Harbor, United States. Mar Pollut Bull 42, 1139-1149.

Zhilina, T. N., Appel, R., Probian, C., Brossa, E. L., Harder, J., Widdel, F. \& Zavarzin, G. A. (2004). Alkaliflexus imshenetskii gen. nov. sp. nov., a new alkaliphilic gliding carbohydrate-fermenting bacterium with propionate formation from a soda lake. Arch Microbiol 182, 244-253. 